\title{
High resolution tsunami modelling for the evaluation of potential risk areas in Setúbal (Portugal)
}

\author{
J. Ribeiro, A. Silva, and P. Leitão \\ HIDROMOD, Modelação em Engenharia, Lisboa, Portugal
}

Received: 31 August 2010 - Revised: 14 July 2011 - Accepted: 19 July 2011 - Published: 26 August 2011

\begin{abstract}
The use of high resolution hydrodynamic modelling to simulate the potential effects of tsunami events can provide relevant information about the most probable inundation areas. Moreover, the consideration of complementary data such as the type of buildings, location of priority equipment, type of roads, enables mapping of the most vulnerable zones, computing of the expected damage on manmade structures, constrain of the definition of rescue areas and escape routes, adaptation of emergency plans and proper evaluation of the vulnerability associated with different areas and/or equipment.

Such an approach was used to evaluate the specific risks associated with a potential occurrence of a tsunami event in the region of Setúbal (Portugal), which was one of the areas most seriously affected by the 1755 tsunami.

In order to perform an evaluation of the hazard associated with the occurrence of a similar event, high resolution wave propagation simulations were performed considering different potential earthquake sources with different magnitudes. Based on these simulations, detailed inundation maps associated with the different events were produced. These results were combined with the available information on the vulnerability of the local infrastructures (building types, roads and streets characteristics, priority buildings) in order to impose restrictions in the production of high-scale potential damage maps, escape routes and emergency routes maps.
\end{abstract}

\section{Introduction}

Since the 2004 Indian Ocean tsunami, the awareness of the European governments on the risks associated with the potential occurrence of a tsunami event has being growing. An example of this is the tsunami warning system (TWS) that

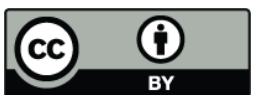

Correspondence to: J. Ribeiro

(joao.ribeiro@hidromod.com) has been implemented by the Intergovernmental Coordination Group for the Tsunami Early Warning and Mitigation System in the North-Eastern Atlantic, the Mediterranean and connected seas.

Similar systems have been developed and are operational in other regions, such as the Pacific Tsunami Warning System (PTWS), the West Coast and Alaska Tsunami Warning Centre (WC/ATWC), the ICG/CARIBE-EWS (which has been conceived with a multi-hazard approach and focused on all coastal hazards) or the Indian Ocean Tsunami Warning System (IOTWS), among others. Most of these systems were designed to cover large areas, but in many places there is a need to establish a regional warning system due to the short time available for an effective response. Such is the case of Portugal, where the average travel time for a tsunami originating in the most probable areas, the South and southwest coasts of the Iberian Peninsula, takes less than 15 min to reach the Portuguese southern coast as discussed in Sect. 4.

In order to improve the capacity of response for a tsunami event, a Portuguese Tsunami Warning System (PtTWS) is being developed by the Meteorological Institute in collaboration with D. Luís Institute and the Joint Research Centre (JRC) and it has been designed to detect tsunami originated from earthquakes. A dense seismic network that operates $24 \mathrm{~h}$ a day, 7 days a week, along with the Tsunami Analysis Tool (TAT), that explores a database of over 6500 scenarios, allows a first evaluation of the tsunami danger by an operator within 5 min of the event onset (Matias et al., 2010).

In any case, despite the improvement of the background infrastructure and the capability of the Portuguese Civil Protection Services to deal with more common hazards (such as floods, fires or even earthquakes), there is still a lack of information about the most probable scenarios that may result from the occurrence of a tsunami. According to a social awareness survey regarding tsunami risk performed in Setúbal, under the SCHEMA project (Scheer et al., 2011), it is perceptible that although most of the inquired persons show a good perception in identifying the risk and the most

Published by Copernicus Publications on behalf of the European Geosciences Union. 
vulnerable areas associated with an earthquake or flooding events, the tsunami hazard is still not seen as a high risk event and there is a lack of association of an earthquake with a tsunami event. In view of these results, one must conclude that it is imperative to develop public awareness concerning this issue.

Conversely, although the Civil Protection Authority shows a high level of preparedness to deal with major hazards such as floods or fires, it does not have specific plans to respond to a tsunami event (or to a more probable combined earthquaketsunami event). For instance, there are detailed maps identifying the most vulnerable areas and escape routes in case of the occurrence of a flood, but there is no similar information for the occurrence of a tsunami. In order to cover this gap, the identification and mapping of the most vulnerable areas using high resolution models can produce a reliable input in the elaboration of evacuation and rescue plans in the case of a tsunami event.

Such simulations were carried out for the area of Setúbal, on the western Portuguese coast, using the MOHID water modelling system (Malhadas et al., 2009) following a methodology common to 5 sites that were investigated within the framework of the SCHEMA project (Setúbal in Portugal, Varna in Bulgaria, Catania in Italy, Rabat in Morocco, and Mandelieu in France). In order to properly evaluate the robustness of MOHID and other models to properly simulate the propagation of a tsunami event, a benchmark based on data available from the 2004 Indian Ocean tsunami impact on the Seychelles islands was performed using 5 different models: MOHID water modelling system, Community Model Interface for Tsunami (ComMIT) base on the Method of Splitting Tsunami model (MOST), UBO-TSUFD model, FUNWAVE model and the TIDAL model. The tide gauge recorder from the Pointe Larue station located at Mahé Island international airport was used to compare the results of the water level and time of arrival measured and computed by the models. Also, the results of maximum inundation depths and current speed were used to benchmark the various models used in the SCHEMA project (Lessons learnt from the Asia test site, www.schemaproject.org/spip.php?rubrique4).

\section{Study site}

The study site is located in the Sado estuary region, on the western coast of Portugal (Fig. 1), and it includes two different areas: Setúbal city and Tróia peninsula.

The Sado Estuary is located $40 \mathrm{~km}$ south of Lisbon and is the second largest estuary in Portugal, with an area of approximately 24000 ha. Most of the estuary is classified as a natural reserve (Reserva Natural do Estuário do Sado). Exception is made for the city of Setúbal, its port, and a considerable part of its surrounding area. With a number of inhabitants of some 120000 and a land area of $170 \mathrm{~km}^{2}$, the population is concentrated mainly in the city of Setúbal.

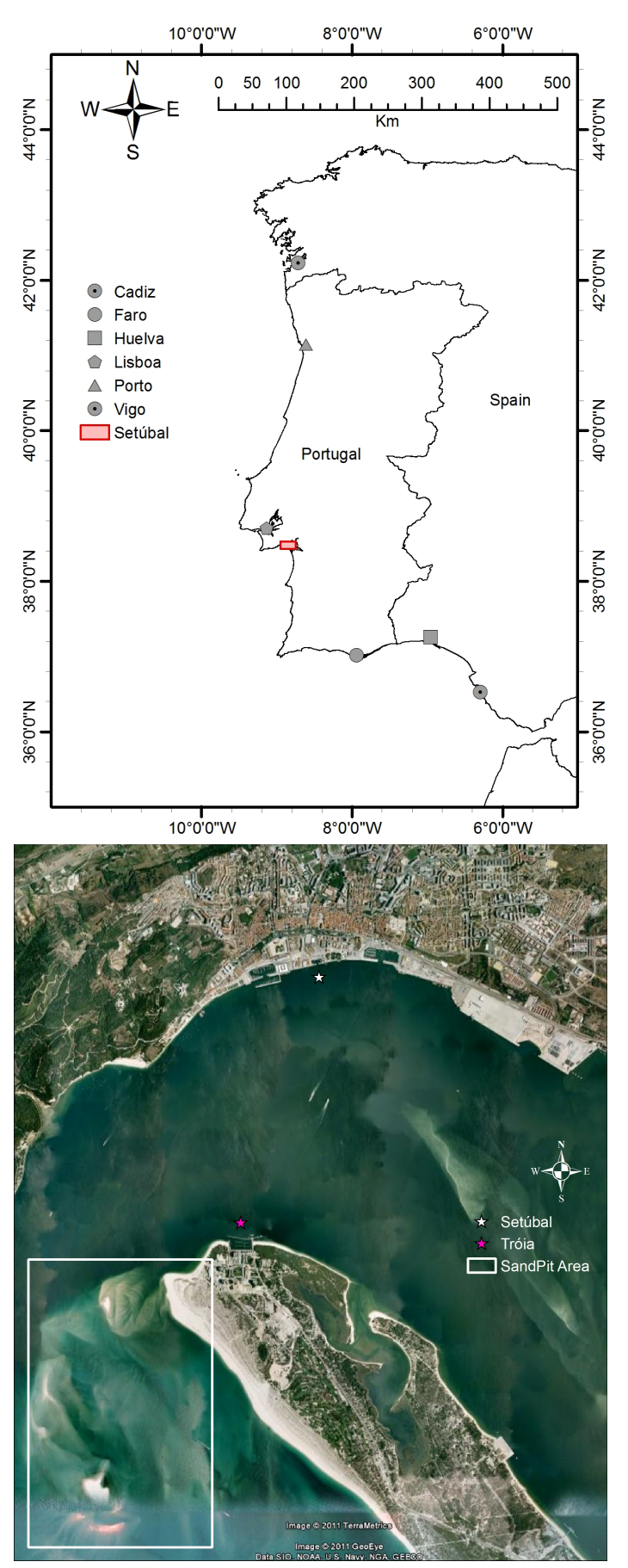

Fig. 1. Location of the test site.

The Tróia peninsula is a low land sand spit that separates the estuary from the ocean where, due to its particular characteristics of long sand beaches, a strong tourism pressure is present. Also due to its location, this area of Tróia peninsula may be particularly vulnerable to a tsunami event. The coastline starts at the Tróia peninsula and extends until Melides, over $45 \mathrm{~km}$ south. 

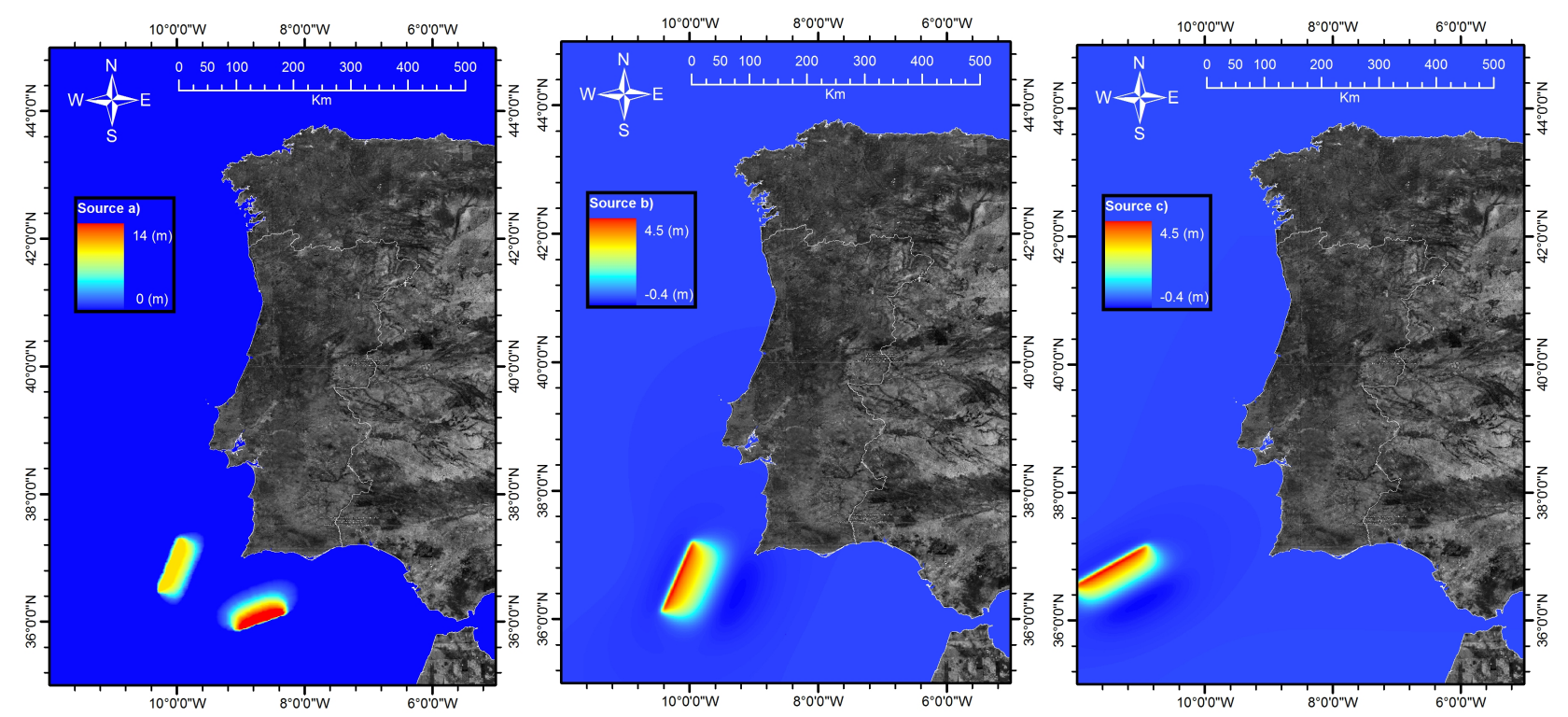

Fig. 2. Source (a): considered the most destructive simulated, Baptista et al. (2003). Source (b): MPF event, considered the moderated case, Omira et al. (2009). Source (c): GBF event, considered the weakest, Omira et al. (2009).

Table 1. The considered scenarios, the fault for each scenario, the length and the width of the faults, depth from the sea bottom to the top of the fault and the moment magnitude.

\begin{tabular}{|c|c|c|c|c|c|c|c|c|c|c|c|}
\hline \multirow[t]{2}{*}{ Scenario } & \multirow{2}{*}{$\begin{array}{r}\mathrm{L} \\
(\mathrm{Km})\end{array}$} & \multirow{2}{*}{$\begin{array}{r}\mathrm{W} \\
(\mathrm{Km})\end{array}$} & \multicolumn{2}{|c|}{ Epicentre coordinates } & \multirow{2}{*}{$\begin{array}{r}\mathrm{D} \\
(\mathrm{Km})\end{array}$} & \multirow{2}{*}{$\begin{array}{r}\text { Slip } \\
\text { (m) }\end{array}$} & \multirow{2}{*}{$\begin{array}{r}\text { Strike } \\
\left({ }^{\circ}\right)\end{array}$} & \multirow{2}{*}{$\begin{array}{r}\text { Dip } \\
\left({ }^{\circ}\right)\end{array}$} & \multirow{2}{*}{$\begin{array}{r}\text { Rake } \\
\left({ }^{\circ}\right)\end{array}$} & \multirow{2}{*}{$\begin{array}{c}\mu \\
(\mathrm{Pa})\end{array}$} & \multirow[t]{2}{*}{$\mathrm{M} \omega$} \\
\hline & & & Lon & & & & & & & & \\
\hline MPTF & 105 & 55 & - & - & - & 20 & 21.7 & 24 & - & - & \\
\hline G. Bank & 96 & 55 & - & - & - & 20 & 70 & 45 & - & - & 8 \\
\hline MPF & 129 & 70 & -9.890 & 36.574 & 4.0 & 8.0 & 20.0 & 35 & 90 & $3.0 \times 10^{10}$ & 8.1 \\
\hline GBF & 127 & 60 & -11.332 & 36.665 & 5.0 & 8.3 & 233.0 & 35 & 90 & $3.0 \times 10^{10}$ & 8.1 \\
\hline
\end{tabular}

\section{$2.1 \quad 1755$ Tsunami}

There has been a significant number of tsunami events registered on the Atlantic coast of the Iberian Peninsula (Baptista and Miranda, 2009). Among them is the well-known 1755 earthquake and tsunami event.

The 1755 earthquake took place on Saturday, 1 November 1755, the Catholic holiday of All Saints' Day, at approximately 09:30 in the morning. The earthquake is considered to have had a seismic intensity of X-XI on the Mercalli Intensity Scale, and it was felt all over Europe (Baptista et al., 1998a). Its magnitude is considered to have been of the order of 8.5 with the epicentre located south/southwest of Cape São Vicente near the Gorringe Bank although there still persists a degree of uncertainty about the precise location of the epicentre and the focal mechanism (Baptista et al., 1998b).

The subsequent tsunami caused by the earthquake produced a large inundation and enhanced the destruction in Lisbon downtown and other coastal villages such as Sétubal.
According to available descriptions, as a result of the combined action of the earthquake and the tsunami, the city walls collapsed which increased the damage and destruction of the inner city. According to a description of the time "the Sea destroyed the city walls entering the city almost a quarter of a mile, carrying 2 boats for more than 50 steps $(\sim 45 \mathrm{~m})$ in land" (Mendonça, 1758), "Letters by the last post notify that no traces are left of St Ubes [Setúbal], the repeated shocks and the vast surf of the sea having jointly concurred to swallow it up. It could withstand them, as it was situated at the head of a small gulf formed by the tide at the mouth of the [Sado]..." URBAN, (1755).

The level of destruction is recorded in other writings of the time, such as the example of the annotation made by the priest of Saint Julian Church: "By 9:30 of November, 1, 1755, a great calamity occurred in Portugal and Spain and some other European countries. The fatal calamity of an earthquake that lasted for a period of 8 minutes during which time this noble village was destroyed, as was the case with Lisbon 
Table 2. Domain Resolution.

\begin{tabular}{llc}
\hline Level & $\begin{array}{l}\text { Grid } \\
\text { Resolution }\end{array}$ & $\begin{array}{c}\text { Grid Size } \\
\text { Lines } \times \text { Columns }\end{array}$ \\
\hline 1 & $0.01^{\circ}$ & $1000 \times 700$ \\
2 & $250 \mathrm{~m}$ & $269 \times 388$ \\
3 & $50 \mathrm{~m}$ & $224 \times 249$ \\
4 & $10 \mathrm{~m}$ & $300 \times 650$ \\
5 & $2 \mathrm{~m}$ & $396 \times 936$ \\
\hline
\end{tabular}

and all the territories adjacent to the water: the main destruction occurred in this village of Setúbal in which almost all the houses and churches were destroyed, including our church of S. Julian (...). and more than four thousand people died in this village, not only as a consequence of the earthquake, but due to the action of the sea which on this fatal day inundated the village three times (....)."

\section{Hydrodynamic model}

In order to evaluate the potential effects of a tsunami event on the downtown area of Setúbal and Tróia peninsula, a number of numerical simulations considering different potential earthquake sources have been performed using MOHID modelling system, which is a three-dimensional finite volume model developed by IST (Technical University of Lisbon) and Hidromod (Martins et al., 2001). MOHID has the ability to simulate flows over complex bathymetries and it has been widely used to simulate flows ranging from shallow coastal systems (Vaz et al., 2009) to deep ocean environments (Riflet et al., 2008). The model uses Navier-Stokes primitive equations with Boussinesq and hydrostatic assumptions. MOHID is a 3-D baroclinic model. However, in this case due to the barotropic nature of the processes involved and in order to increase computational efficiency, a 2-D approach (only one vertical layer) was followed. The model takes into consideration the existence of moving boundaries which allows the simulation of the inundation processes (Martins et al., 2001). At the bottom, advective fluxes are imposed as null and the diffusive flux of momentum is estimated by means of a bottom stress calculated by a non-slip method with a quadratic law that depends on the near-bottom velocity. This quadratic law is derived from the logarithmic law of the wall near boundaries characteristic of boundary layers, as the bottom velocities are located half a grid box above the bottom. This term is calculated semi-implicitly following Backhaus (1983) for numerical stability reasons. The model solves a semi-implicit ADI algorithm to compute the water level evolution with two time levels per iteration. The two components of the horizontal velocity are globally centred in time $t+\mathrm{d} t / 2$ leading to a second order time accuracy (Martins et al., 2001). MOHID allows the user to construct a tree of

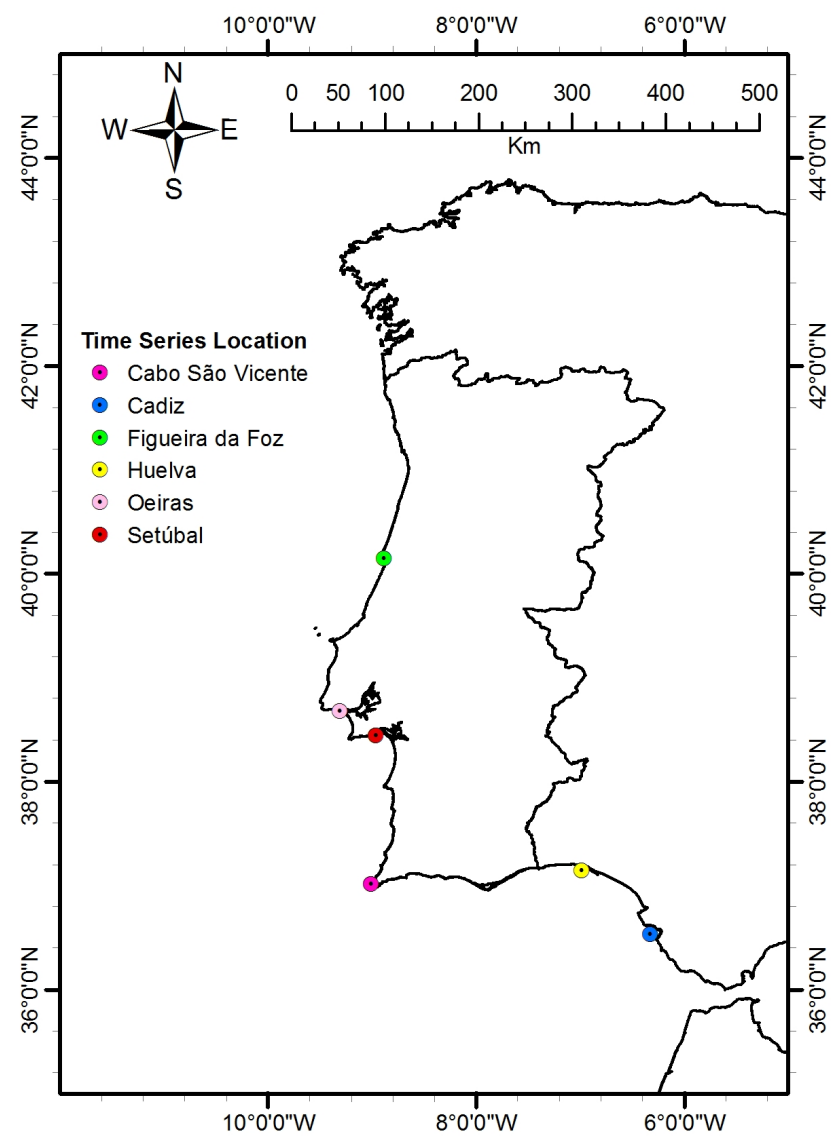

Fig. 3. Time series location points for the Portuguese coast.

nested models with no limitations on the number of nesting levels (Braunschweig et al., 2004). Between nesting levels a radiation boundary condition proposed by Flather (1976) is used. A one-way nesting approach with interpolation in the horizontal and linear interpolation in the vertical and in time is followed. A detailed description of the nesting methodology is presented in Leitão et al. (2005).

The system also allows adding the tide level based on global tide solution FES2004 (Lyard et al., 2006).

\subsection{Simulations}

In this study, three different possible tsunami sources corresponding to different faults and therefore different initial sea level displacements were simulated. These sources (Fig. 2, Table 1) representing high, medium and low destructive conditions were adopted from different proposals available in the literature regarding possible earthquake sources southwest of the Portuguese coast (Omira et al., 2009; Baptista et al., 2003).

The most destructive source (Table 1) selected for simulation corresponds to an interpretation of the origins of the 1755 earthquake proposed by Baptista et al. (2003). The two other possible sources considered, the Gorringe Bank Fault 
Table 3. Results of simulated events for Setúbal.

\begin{tabular}{llccclcc}
\hline Scenario & $\begin{array}{l}\text { Tide } \\
(\mathrm{min})\end{array}$ & $\begin{array}{c}\text { Travel Time } \\
(\mathrm{m})\end{array}$ & $\begin{array}{c}\text { Wave height } \\
\text { Level Inland }(\mathrm{m})\end{array}$ & $\begin{array}{c}\text { Max. Water } \\
\text { Distance }(\mathrm{m})\end{array}$ & $\begin{array}{l}\text { Max. Inundation } \\
\text { Inland }\left(\mathrm{m} \mathrm{s}^{-1}\right)\end{array}$ & $\begin{array}{c}\text { Max. Velocity } \\
(\mathrm{m})\end{array}$ & Water Column \\
\hline MPTF & High & 30 & 6.87 & $7-8$ & 859 & $>3$ & 3 \\
G. Bank & Low & 30 & 4.98 & $5-6$ & 206 & $1.5-2$ & $1.5-2$ \\
\hline \multirow{2}{*}{ MPF } & High & 32 & 5.19 & $4-5$ & 578 & $1.5-2$ & $1.5-2$ \\
& Low & 32 & 3.26 & & No Inundation & & \\
\hline \multirow{2}{*}{ GBF } & High & 35 & 5.05 & $5-6$ & 419 & $1-1.5$ & $0.5-1$ \\
& Low & 35 & 3.13 & & No Inundation & & \\
\hline
\end{tabular}
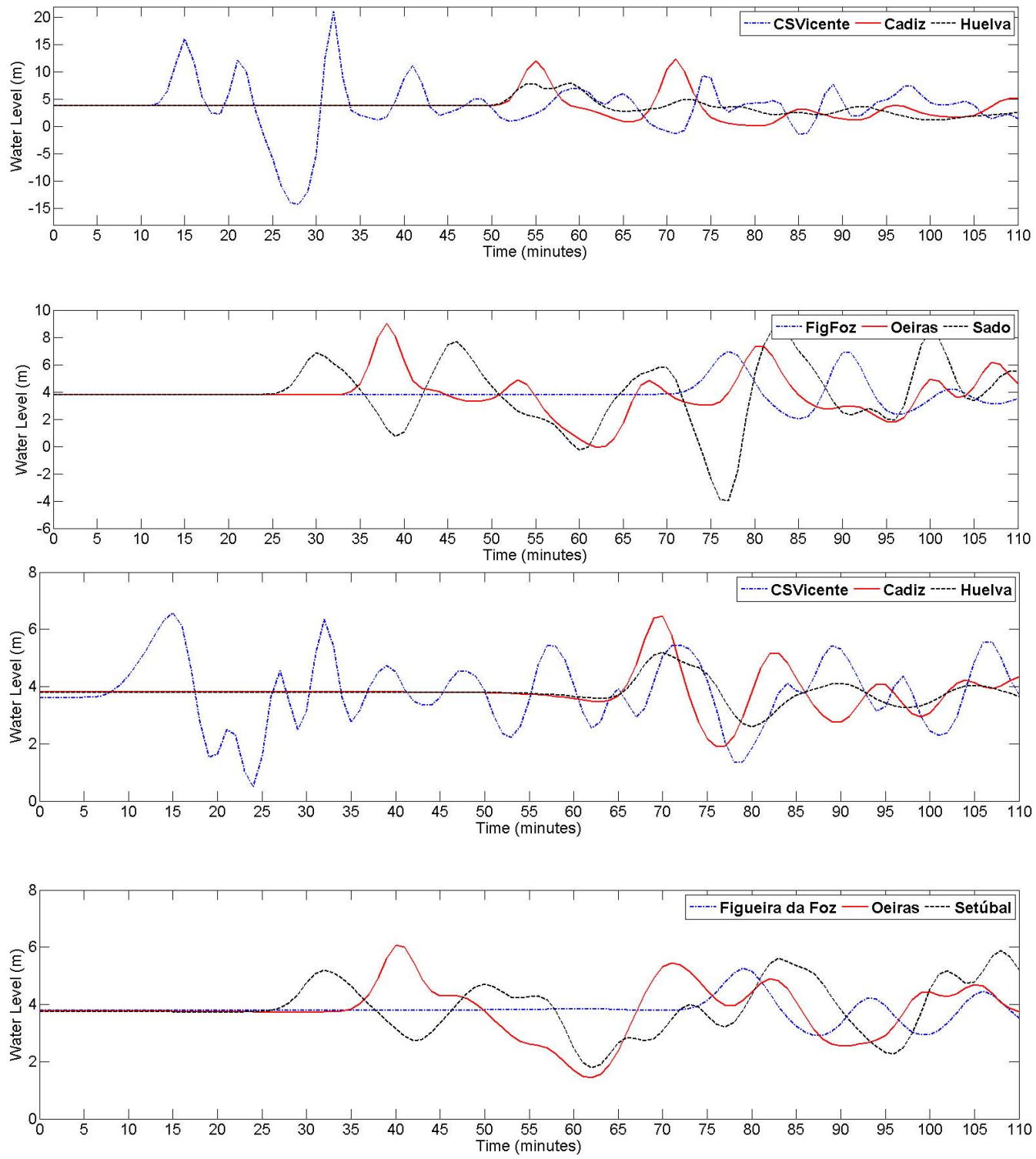

Fig. 4. Top: time series for source (a), Middle: time series source (b), Bottom: time series for source (c). 


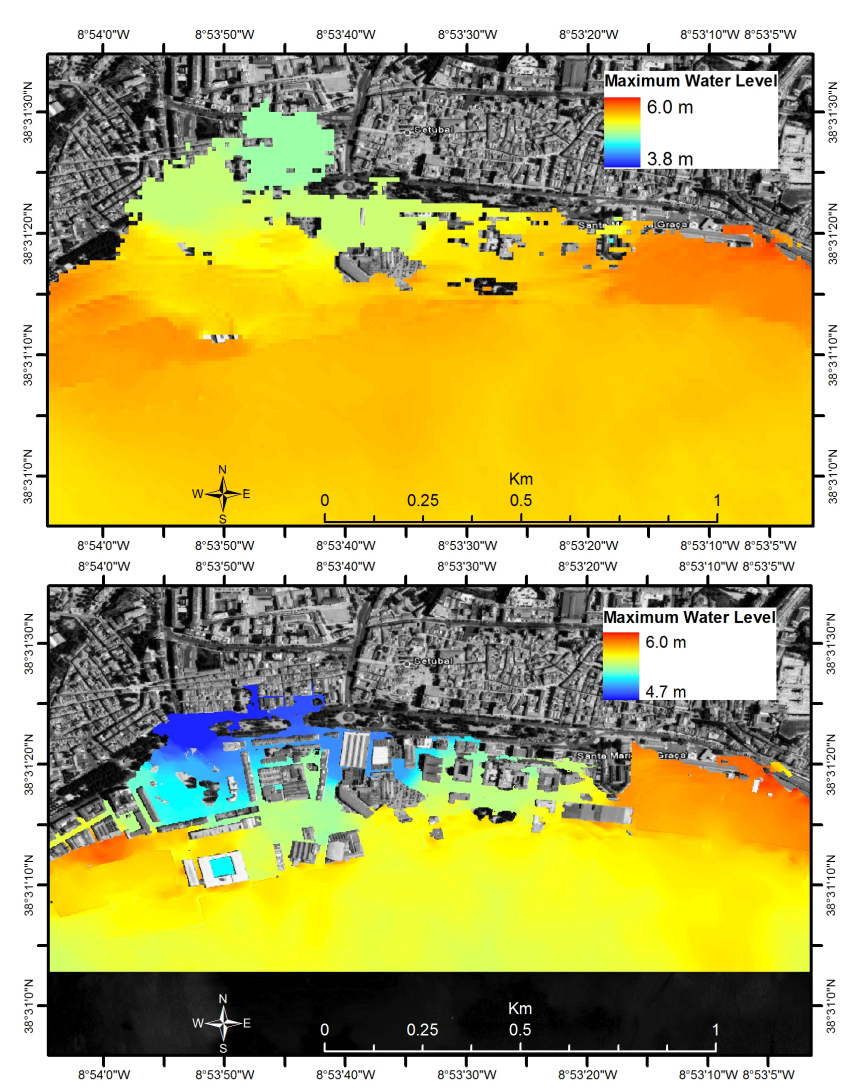

Fig. 5. Setúbal Inundation areas considering topography only (top) and including buildings (bottom).

and the Marquês de Pombal Bank Fault, are based on a study done by Omira et al. (2009) regarding the design of a Sealevel Tsunami Detection Network for the Gulf of Cadiz.

The simulations consisted in four level nested grids with a fifth level only for the city of Sétubal that has incorporated the detailed building information.

For the first level, the SRTM 30 data were used to build a computational grid with a resolution of $0.01^{\circ}$ (Table 2). The second level $(250 \mathrm{~m}$ resolution grid) is based on data retrieved from a combination of nautical charts and acoustic surveys. For the third level, a regular grid with $50 \mathrm{~m}$ resolution was prepared using a combination of nautical charts and mostly acoustic surveys. For the fourth level, a $10 \mathrm{~m}$ resolution grid using detailed bathymetric information of the navigation channels obtained by acoustic surveys was set up. The lowest level located at the city of Setúbal consists of a $2 \mathrm{~m}$ resolution grid including the detailed bathymetry of the navigation channels and the information on the building characteristics.

Two tide levels, referenced to the Portuguese hydrographic zero, were selected, given that tide level plays a most relevant role in the potential inundation areas: a high tide situation corresponding to a $3.8 \mathrm{~m}$ water level and a low tide situation corresponding to a $1.8 \mathrm{~m}$ water level, all altitudes referred to hydrographic zero.

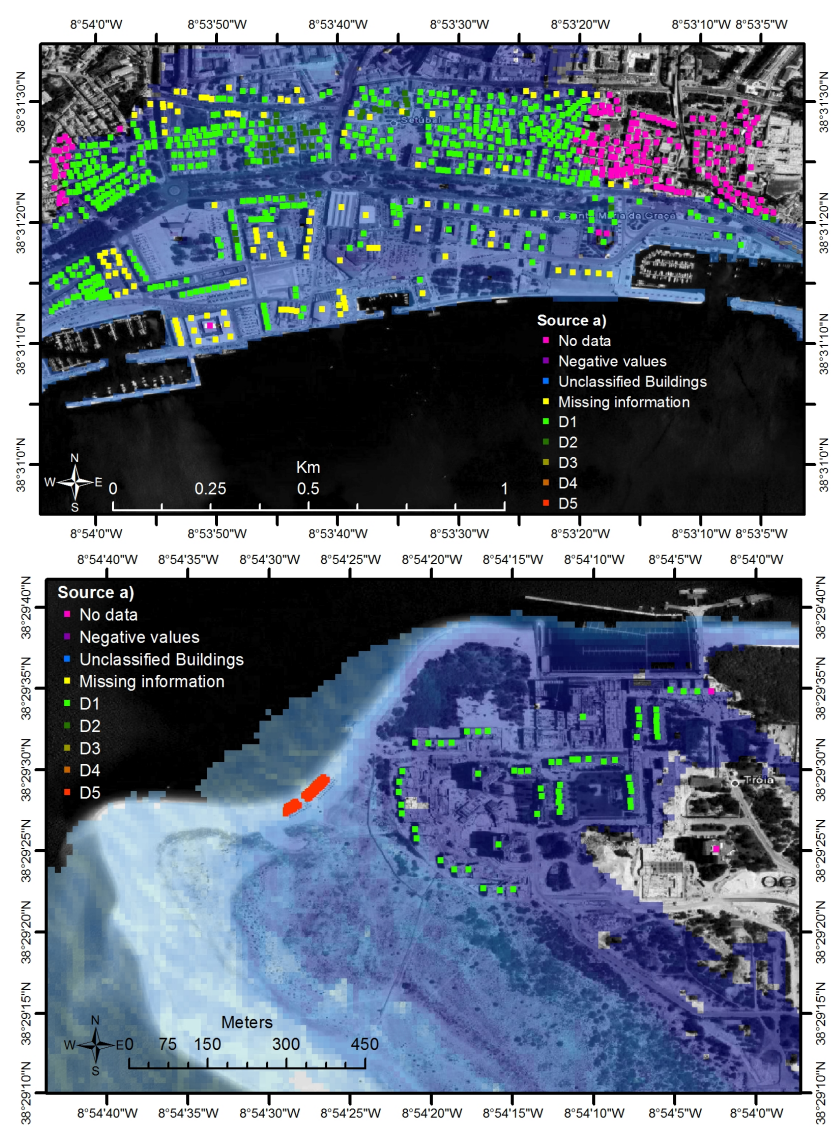

Fig. 6. Damage calculated by the Damasche tool for the Setúbal and Tróia buildings.

For the region of Setúbal and Tróia, a survey of the building characteristics, roads, parking and marinas was done using Google Earth, Bing (for 3-D view) and local photography. The building vulnerability classification as regards tsunami hazard was performed according to the classification adopted in SCHEMA that is principally derived from Leone et al. (2006), but has been completed and enlarged in order to include at least all constructions present in all test sites of the SCHEMA (Scheer et al., 2011). Four main classes of buildings have been defined in the classification, divided into sub-classes on the basis of their structural characteristics of resistance - the lowest class corresponds to light constructions (A), masonry construction and not reinforced concrete constructions (B, C and D), reinforced concrete constructions (E) and the higher class corresponds to other constructions ( $F$ and $\mathrm{G})$.

The damage scale adopted in SCHEMA makes use of 6 levels of damage and was adopted from the work of Leone et al. (2010), Peiris (2007) and Garcin et al. (2007) (Scheer et al., 2011). The 6 levels correspond to no damage (D0), light damage (D1), important damage (D2), heavy damage (D3), partial failure (D4) and collapse (D5). 
Table 4. Results for selected locations.

\begin{tabular}{|c|c|c|c|c|c|}
\hline \multirow{2}{*}{ Scenario } & \multirow{2}{*}{ Location } & \multicolumn{2}{|c|}{ High Tide } & \multicolumn{2}{|c|}{ Low Tide } \\
\hline & & $\begin{array}{l}\text { Travel Time } \\
(\mathrm{min})\end{array}$ & $\begin{array}{l}\text { Wave height } \\
\text { (m) }\end{array}$ & $\begin{array}{l}\text { Travel Time } \\
(\mathrm{min})\end{array}$ & $\begin{array}{l}\text { Wave height } \\
\text { (m) }\end{array}$ \\
\hline \multirow{5}{*}{ MPTF G. Bank } & Figueira da Foz & 77 & 6.98 & 78 & 4.96 \\
\hline & Oeiras & 38 & 9 & 39 & 6.77 \\
\hline & Cabo São Vicente & 15 & 16.25 & 15 & 14.2 \\
\hline & Huelva & 54 & 7.94 & 55 & 5.82 \\
\hline & Cadiz & 55 & 12.1 & 56 & 10 \\
\hline \multirow{5}{*}{ MPF } & Figueira da Foz & 79 & 5.26 & 80 & 3.26 \\
\hline & Oeiras & 40 & 6.08 & 43 & 3.95 \\
\hline & Cabo São Vicente & 15 & 6.58 & 15 & 4.61 \\
\hline & Huelva & 70 & 5.20 & 71 & 3.18 \\
\hline & Cadiz & 70 & 6.48 & 71 & 4.59 \\
\hline \multirow{5}{*}{ GBF } & Figueira da Foz & 77 & 6.26 & 78 & 4.30 \\
\hline & Oeiras & 42 & 6.00 & 43 & 3.95 \\
\hline & Cabo São Vicente & 24 & 5.27 & 25 & 3.29 \\
\hline & Huelva & 81 & 4.41 & 82 & 2.40 \\
\hline & Cadiz & 80 & 4.93 & 81 & 3.00 \\
\hline
\end{tabular}

For the evaluation of the damage suffered by the buildings, an ArcGis tool developed within the framework of the SCHEMA project was used. The Damage Assessment SCHEMA tool (DamASCHE) is able to assess the potential building damage in an area where a hazard like a tsunami has been modelled and a building vulnerability matrix exists (Tinti et al., 2011). In this case, for the damage assessment the modelled parameter was the water column present in the inundation area.

For the larger computing scales, times series based on the study from Baptista et al. (2003) corresponding to different locations along the Portuguese coast (Fig. 3) were also analyzed.

\section{Results and discussion}

\subsection{Coastal scale}

For the most destructive scenario (Fig. 2: source a), the first wave to reach the Sado Estuary (Table 3) has a height of about $7 \mathrm{~m}$ and takes about $30 \mathrm{~min}$ to travel from the source to Setúbal. During the simulation period the highest wave registered measures approximately $9 \mathrm{~m}$ and occurs one hour and twenty minutes after the beginning of the event. If we consider a set of synthetic mareograms as described in Table 4 , selected to output time series, the most significant one is the Cape of São Vicente where the wave arrives just fifteen minutes after the beginning of the event with a wave height of $16 \mathrm{~m}$. As for the other relevant locations selected along the
Portuguese coast, Oeiras (near Lisbon), was hit 8 min later than Setúbal with a $9 \mathrm{~m}$ wave.

In the case of the moderated scenario (source b in Fig. 2) event, the first wave took approximately $32 \mathrm{~min}$ to reach the Sado Estuary with a height of about $5 \mathrm{~m}$. In comparison with the previous scenario, this is almost $2 \mathrm{~m}$ lower. The Cape of São Vicente registered an initial wave of about $6.5 \mathrm{~m}$, which took approximately fifteen minutes to arrive and the wave arrived at Oeiras $8 \mathrm{~min}$ after reaching Sado with a height of approximately $6 \mathrm{~m}$ and Figueira da Foz registered a wave measuring $5 \mathrm{~m} 39 \mathrm{~min}$ after arriving in Oeiras. In the case of the weaker scenario (source c in Fig. 2), the arrival of the first wave occurs five minutes later than the time that was computed for the first event, corresponding to a travel time of $35 \mathrm{~min}$.

When comparing these results with the gathered information and the results achieved by Omira et al. (2009) and Baptista et al. (2003), the MOHID model generally exhibits significant agreement. The differences registered may be due to the different models used: SWAN (Mader, 1988) for the first study and an implementation of COMCOT (Liu et al., 1998) for the second, the consideration of high tide and low tide, the grid resolution, and also bathymetric data.

The overall results for all the referred stations can be seen in Table 3 and Fig. 4.

\subsection{Local scale}

Using the local scale results obtained for the $10 \mathrm{~m}$ grid, it was possible to make a detailed evaluation of the extension and relevance of the most probable inundation areas, both 
Table 5. Damage Table.

\begin{tabular}{lccc|cccc}
\hline Class & $H_{\min }$ & $H_{\max }$ & Damage & Class & $H_{\min }$ & $H_{\max }$ & Damage \\
\hline $\mathrm{A}$ & 0 & 0 & 0 & $\mathrm{C}$ & 4 & 6 & 3 \\
$\mathrm{~A}$ & 0 & 1.8 & 1 & $\mathrm{C}$ & 6 & 8 & 4 \\
$\mathrm{~A}$ & 1.8 & 2.2 & 2 & $\mathrm{C}$ & 8 & 9999 & 5 \\
$\mathrm{~A}$ & 2.2 & 2.6 & 3 & $\mathrm{D}$ & 0 & 0 & 0 \\
$\mathrm{~A}$ & 2.6 & 3.8 & 4 & $\mathrm{D}$ & 0 & 2 & 1 \\
$\mathrm{~A}$ & 3.8 & 9999 & 5 & $\mathrm{D}$ & 2 & 4.5 & 2 \\
$\mathrm{~B}$ & 0 & 0 & 0 & $\mathrm{D}$ & 4.5 & 6.5 & 3 \\
$\mathrm{~B}$ & 0 & 2 & 1 & $\mathrm{D}$ & 6.5 & 9 & 4 \\
$\mathrm{~B}$ & 2 & 3 & 2 & $\mathrm{D}$ & 9 & 9999 & 5 \\
$\mathrm{~B}$ & 3 & 4 & 3 & $\mathrm{E}$ & 0 & 0 & 0 \\
$\mathrm{~B}$ & 4 & 5 & 4 & $\mathrm{E}$ & 0 & 3 & 1 \\
$\mathrm{~B}$ & 5 & 9999 & 5 & $\mathrm{E}$ & 3 & 6 & 2 \\
$\mathrm{C}$ & 0 & 0 & 0 & $\mathrm{E}$ & 6 & 9.5 & 3 \\
$\mathrm{C}$ & 0 & 2.5 & 1 & $\mathrm{E}$ & 9.5 & 12.5 & 4 \\
$\mathrm{C}$ & 2.5 & 4 & 2 & $\mathrm{E}$ & 12.5 & 9999 & 5 \\
\hline
\end{tabular}

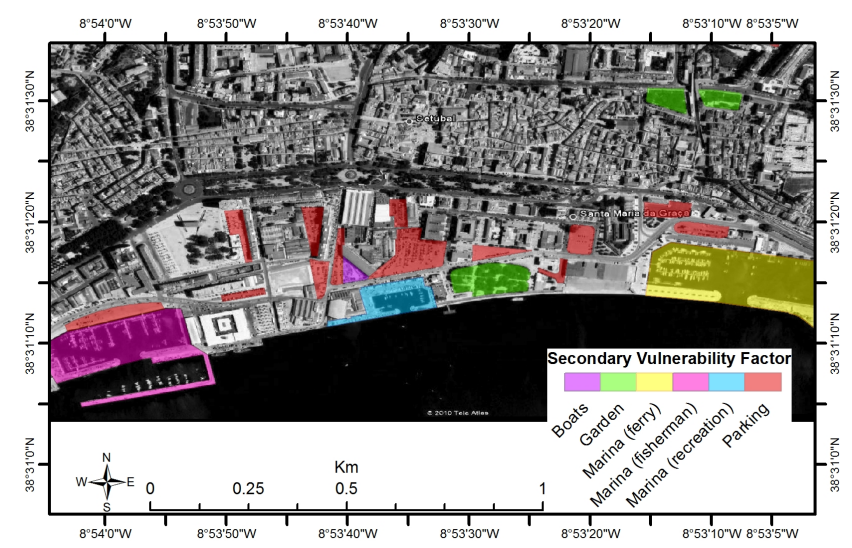

Fig. 7. Secondary vulnerability factors zones.

in what concerns the Tróia peninsula and Setúbal city. In the case of Tróia Peninsula, the most affected areas are the beach and the tip of the peninsula where the Tróia resort is located. The inundation in these areas can reach up to $600 \mathrm{~m}$ inland and a water level of 8 to $9 \mathrm{~m}$ can be reached around the buildings area. In these areas velocities higher than $3 \mathrm{~m} \mathrm{~s}^{-1}$ were calculated.

For Setúbal city, in the case of the stronger event, the maximum water level lies between 6 and $8 \mathrm{~m}$ and one can see that the entire shoreline suffers a relevant impact. The inundation can reach $850 \mathrm{~m}$ inland, causing the inundation of the historical centre. Here, velocities can range from $0.6 \mathrm{~m} \mathrm{~s}^{-1}$ to higher than $3 \mathrm{~m} \mathrm{~s}^{-1}$, although the analysis of the velocities must be done with some caution since the values reached in low water or land areas are expected not to be very trustworthy due to the limitations of the computational process and the complexity of the geometry.
In Table 4 an overall view of the results on the synthetic mareograms for the different sources can be seen.

For the city of Setúbal, a fifth computing level including the building information was modelled with the main purpose of evaluating to what extent the inclusion of this information might influence the conclusions concerning the inundation areas. In order to do this simulation, it was necessary to build a computational grid with accuracy enough to be able to represent the buildings and the roads in between them. Although the results of these simulations need to be carefully analyzed, as they may lead to a false impression of accuracy due to the extreme detail of the flow, they are extremely useful if used as a sensitivity analysis. A major conclusion is that the building information can take a significant role, both in the way the inundation occurs and in what concerns its extension (Fig. 5). Comparing the results with topography only and with the extra flow propagation obstacles composed by the buildings, one may, at least, have a confidence interval in what concerns the mapping of the inundation areas.

\subsection{Vulnerability analysis}

For sources $\mathrm{a}$ and $\mathrm{b}$, a comparison of high and low tide impact was done for the local scenarios of Tróia and Setúbal. The maximum of all modelled scenarios at low and high tide was extracted and mapped showing the relevance of the tide level in the inundation areas.

In Setúbal the building classification can go from $\mathrm{C}$ to $\mathrm{G}$. The D class is mostly located in the historical part of the town and is also the most common class found. The $\mathrm{C}$ class can be found mostly near the fishing marina and refers to some old fisherman houses. The $\mathrm{G}$ class are warehouses, important buildings and administrative buildings. Here, the maximum inundation observed from all the modelled scenarios 
can reach the old town centre affecting administrative buildings, restaurants and warehouses. The highest level of damage (Fig. 6, Table 5) suffered by buildings in Setúbal for all the scenarios is D2.

In the case of Tróia, some A class structures used as beach support infrastructures that can be found on the beach may suffer D5 damage levels. Nevertheless, most of the buildings in this area can be classified as D or F and only show vulnerability to damages of D1 class level.

In what concerns the routes classification, it was concluded that the streets in Setúbal and Tróia cover a wide width range scale ( 1 to $10 \mathrm{~m}$ wide). In a worst-case scenario, all the roads near the seaside are affected; such is the case of the main road that crosses the town centre and is linked to the other major access points to the town. Inside the historical area there are mostly narrow streets that serve mainly for the local population and commerce. With an event like that of source a), all these roads would remain inundated and this would limit rescue efforts. In the case of Tróia, the streets are narrow and there is only one road that goes in and out of the resort. With an event like that of source one, the streets are at a high risk to remain flooded.

An additional factor that can contribute to increasing the damage are the parking areas located near shore, as a car may easily float and hit buildings (Fig. 7). Similar secondary damage factors may be identified in the marinas, as the parked cars, docked boats and fishing devices, such nets and traps, may become additional damage factors for people, buildings and rescue crews.

\section{Conclusions}

In order to perform an evaluation of the vulnerability associated with the occurrence of a tsunami event in the Setúbal area, we made a number of high resolution wave propagation simulations considering different potential earthquake sources with different magnitudes. As a result, detailed inundation maps combined with the available information of the local infrastructures were able to produce high scale vulnerability maps, escape routes and emergency routes maps.

The results show that significant population areas are at risk to be affected; such are the cases of Setúbal and Tróia where urban development should be carefully planned taking into consideration the vulnerability of the areas to a tsunami event.

With the implementation of the early warning system, which is designed to provide a tsunami warning with a time delay of $10 \mathrm{~min}$ for confirmation, the Civil Protection Authorities will have a maximum time interval of approximately $20 \mathrm{~min}$ to activate mitigation measures against the occurrence of a tsunami. It should also be taken into consideration that, as in 1755 , for such an event a previous earthquake had likely already occurred.
The type of information provided by high resolution models, such as the one presented in this paper, can be very useful in the development of maps for identifying risk areas, creating evacuation plans, deployment of signalization for evacuation routes, and deployment of rescue teams and adequate equipment. If used in combination with other emergency plans that already exist, it will contribute to better and quicker responses, save rescue crew lives and avoid constraints caused by a previous earthquake. It will also contribute to improve the flow of general information to the population through lectures, brochures, radio, and newspapers.

Acknowledgements. The authors would like to express special thanks to the Setúbal and Grândola Civil Protection Authorities and to the Setúbal Port Authority that provided support and data to the project.

The authors would like to acknowledge the Tsunami Research Team operating at the Department of Physics, Sector of Geophysics of the University of Bologna (Italy), and in particular Dr. Alberto Armigliato, for computing and providing tsunami initial conditions.

The SCHEMA Project was partially funded by the European Commission within the framework of the 6th FP Program, GMES initiative, contract SST5-CT-2006-030963.

Edited by: S. Tinti

Reviewed by: J. Miranda and another anonymous referee

\section{References}

Backhaus, J.: A semi-implicit scheme for the shallow water equations for application to shelf sea modeling, Cont. Shelf Sea Res., 2(4), 243-254, 1983.

Baptista, M. A., Heitor, S., Miranda, J., Miranda, P., and Mendes, L.: The 1755 Lisbon Tsunami; evaluation of the tsunami parameters, J. Geodynamics, 25(2), 143-157, 1998a.

Baptista, M. A., Miranda, P. M. A., Miranda, J. M., and Mendes, L.: Constrains on the source of the 1755 Lisbon tsunami inferred from numerical modeling of the historical data on the source or the 1755 Lisbon tsunami, J. Geodynamics, 25(2), 159-174, $1998 b$.

Baptista, M. A. and Miranda, J. M.: Revision of the Portuguese catalog of tsunamis, Nat. Hazards Earth Syst. Sci., 9, 25-42, doi:10.5194/nhess-9-25-2009, 2009.

Baptista, M. A., Miranda, J. M., Chierici, F., and Zitellini, N.: New study of the 1755 earthquake source based on multi-channel seismic survey data and tsunami modeling, Nat. Hazards Earth Syst. Sci., 3, 333-340, doi:10.5194/nhess-3-333-2003, 2003.

Bing maps, available at: http://www.bing.com/maps/, 2010.

Braunschweig, F., Chambel, P., Fernandes, L., Pina, P., Neves, R., The object-oriented design of the integrated modelling system MOHID, Computational Methods in Water Resources International Conference, North Carolina, USA, 55, 1079-1090, June 13-17, 2004.

Flather, R. A.: A tidal model of the northwest European continental shelf, Mémoires Société Royale des Sciences de Liege, 6(10), 141-164, 1976.

Garcin, M., Prame, B., Attanayake, N., De Silva, U., Desprats, J. F., Fernando, S., Fontaine, M., Idier, D., Lenotre, N., Pedreros, 
R.: C.H.E.R. Siriwardana: A Geographic Information System for Coastal Hazards. Application to a pilot site in Sri Lanka (Final Report), BRGM Open file BRGM/RP-55553-FR, 124 pp., 2007. Google earth: available at: http://earth.google.com/, 2010.

IOC/UNESCO, IOC Tsunami information: available at: http:// www.ioc-tsunami.org/, 2010.

Leendertsee, J. and Liu, S.: A three-dimensional turbulent energy model for non-homogeneous estuaries and coastal sea systems, Hydrodynamics of Estuaries and Fjords, edited by: Nihoul, J., Elsevier, Amsterdam, 387-405, 1978.

Leitão, P., Coelho, H., Santos, A., and Neves, R.: Modeling the main features of the Algarve coastal circulation during July 2004: a downscaling approach, J. Atmos. Ocean Sci., 10(4), 421-462, 2005.

Leone, F., Denain, J. C., Vinet, F., and Bachri, S.: Analyse spatiale des dommages au bâti de Banda Aceh (Sumatra, Indonésie): contribution à la connaissance du phénomène et à l'élaboration de scénarios de risque tsunami. Scientific report of Tsunarisque (2005-2006) programme, 2006.

Leone, F., Lavigne, F., Paris, R., Denain, J. C., and Vinet F.: A spatial analysis of the December 26th, 2004 tsunami-induced damages: Lessons learned for a better risk assessment integrating buildings vulnerability, Appl. Geogr., 31(1), 363-375, 2010.

Liu, P., Woo, S.-B., and Cho, Y.- S.: Computer programs for Tsunami propagation and inundation, Cornell University, 111 pp., 1998.

Lyard, F., Lefevre, F., Letellier, T., and Francis, O.: Modelling the global ocean tides: insights from FES2004, Ocean Dynam., 56, 394-415, 2006.

Mader, C.: Numerical modelling of water waves, Los Alamos Series in Basic and Applied Siences, 206 pp., 1988.

Malhadas, M. S., Leitão, P. C., Silva, A., and Neves, R.: Effect of coastal waves on sea level in Óbidos Lagoon, Portugal, Cont. Shelf Res., 29(9), 1240-1250, 2009.

Martins, F., Neves, R. J., Leitão, P. C., and Silva. A. J. R.: 3-D modelling in the Sado estuary using a new generic coordinate approach, Oceanol. Acta, 24, 51-62, 2001.
Matias, L., Annunziato, A., Baptista, M., and Carrilho, F.: Testing the decision support tools of the tsunami warning system in Portugal (PtTWS), ESC General Assembly, Montpellier, France, 6-10 September 2010, TS/TU/01, 2010.

Mendonça, J. M.: História Universal dos Terramotos que tem havido no mundo de que há notícia desde a sua criação até ao século presente, Biblioteca Nacional de Lisboa, Portugal, 272 pp., 1758.

Omira, R., Baptista, M. A., Matias, L., Miranda, J. M., Catita, C., Carrilho, F., and Toto, E.: Design of a Sea-level Tsunami Detection Network for the Gulf of Cadiz, Nat. Hazards Earth Syst. Sci., 9, 1327-1338, doi:10.5194/nhess-9-1327-2009, 2009.

Pacific Tsunami Warning Center: available at: http://ptwc.weather. gov/ptwc/responsibilities.php, 2010.

Peiris, N.: Vulnerability functions for tsunami loss estimation, First European Conference on Earthquake Engineering and Seismology, Geneva, Switzerland, 2006.

Riflet, G., Juliano, M., Fernandes, L., Leitão, P. and Neves, R.: Operational ocean forecasting of the Portuguese waters, MercatorOcéan Quarterly Newsletter, 30, 20-32, 2008.

Scheer, S., Gardi, A., Guillande, R., Eftichidis, G., Varela, V., de Vanssay, B., and Colbeau-Justin, L.: Handbook of Tsunami evacuation planning, JRC, 61202, Luxembourg: Publications Office of the European Union, Italy, 54 pp., 2011.

Schema project: available at: http://www.schemaproject.org/spip. php?page=sommaire, 2011.

Tinti, S., Tonini, R., Bressan, L., Armigliato, A., Gardi, A., Guillande, R., Valencia, N., and Scheer, S.: Tsunami damage scenarios, in: Handbook on Tsunami Hazard and Damage Scenarios, JRC, 61463, Luxembourg, Publications Office of the European Union, Italy, p. 27, 2011.

Urban, S.: The Gentleman's Magazine, printed by: Henry, D. and Cave, R., St. John' Gate, London, 554-564, 1755.

Vaz, N., Dias, J. M., and Leitão, P. C.: Three-dimensional modelling of a tidal channel: The Espinheiro Channel (Portugal), Cont. Shelf Res., 29, 29-4, 2009. 